\title{
Wall shear stress: effective parameter for the characterisation of the cross-flow transport in turbulent regime during skimmed milk microfiltration
}

\author{
Geneviève Gésan-Guiziou*, Georges Daufin, Evelyne Boyaval, \\ Olivier Le Berre
}

Laboratoire de recherches de technologie laitière, Inra, 65, rue de Saint-Brieuc, 35042 Rennes cedex, France

(Received 2 July 1998; accepted 6 October 1998)

\begin{abstract}
Some experimental evidence is accumulating in the literature which shows that the mean cross-flow velocity is not an effective parameter for the characterisation of the cross-flow transport in membrane separation processes. The aim of this work was to determine the most appropriate parameters (among the wall shear stress, $\tau_{\mathrm{w}}$, the wall shear rate, $\gamma$, the Reynolds number, Re, and the mean cross-flow velocity, $v$ ) that should be used to assess the limiting and critical fluxes in turbulent regime. The experiments were applied to skimmed milk microfiltration (MF) using a tubular ceramic membrane $(0.1 \mu \mathrm{m}$ mean pore diameter $)$ for the separation of casein micelles from the solluble proteins. These experiments were conducted with several membrane geometries (seven or 19 channels, 40 or $85.6 \mathrm{~cm}$ long) and several rigs. Unlike Re and v, $\tau_{\mathrm{w}}$ made it possible to assess the limiting and critical permeation fluxes in milk MF $(0.1 \mu \mathrm{m})$, whatever the membrane geometry. It was consequently concluded to be an effective parameter to account for cake filtration and to study the crossflow filtration scale-up. The wall shear rate, calculated by assuming the turbulence damped at the membrane surface and the flow laminar, was not suitable for the assessment of the limiting and critical fluxes in turbulent regime. (C) Inra/Elsevier, Paris.
\end{abstract}

wall shear stress / hydrodynamics / critical permeation flux / cross-flow microfiltration / skimmed milk

Résumé - La contrainte de cisaillement à la membrane : paramètre pertinent pour caractériser l'écoulement tangentiel en régime turbulent durant la microfiltration tangentielle de lait écrémé. L'objectif de ce travail est de montrer que la contrainte de cisaillement à la membrane est un paramètre approprié pour caractériser l'écoulement tangentiel dans les opérations de séparations par membranes en régime turbulent. Les expériences de microfiltration tangentielle de lait écrémé sur une

\footnotetext{
* Correspondence and reprints. gesan@labtechno.roazhon.inra.fr
} 
membrane de 0,1 micromètre de diamètres de pores (séparation micelles de caséines / protéines du lactosérum) ont été réalisées avec différentes géométries de membranes et différents pilotes de filtration en utilisant la circulation du perméat à cocourant du rétentat. À la différence du nombre de Reynolds et de la vitesse moyenne d'écoulement tangentielle, la contrainte de cisaillement à la membrane permettait de déterminer les flux de perméation limite et critique quelle que soit la géométrie de la membrane (nombre de canaux, diamètre hydraulique, longueur). Cette grandeur était donc pertinente pour rendre compte des performances des séparations sur membranes et pour étudier les changements d'échelle. Le taux de cisaillement à la membrane, calculé en faisant l'hypothèse d'un écoulement laminaire à la surface de la membrane, n'était pas approprié à l'évaluation des flux de perméation critique et limite en régime turbulent. Des études complémentaires devront être réalisées pour déterminer la possible pertinence de ce paramètre vis-à-vis de la caractérisation de l'écoulement tangentiel. (c) Inra/Elsevier, Paris.

contrainte de cisaillement / hydrodynamique / flux de perméation critique / microfiltration tangentielle / lait écrémé

\section{INTRODUCTION}

The practical application of microfiltration (MF) is often limited by severe fouling of the membrane. To reduce this fouling, MF is often carried out in cross-flow mode in which a tangential flow transports material away from the membrane. Many mechanisms (Brownian diffusion, hydrodynamic diffusion, erosion, etc.) have been suggested to explain the steady-state flow commonly observed in cross-flow MF, which occurs in spite of the continuous convective solids mass towards the membrane. All of the models predict that the limiting flux $\left(\mathrm{J}_{\text {lim }}\right.$, which is the permeation flux independent of the pressure and obtained when high transmembrane pressures are applied) depends on cross-flow transport [3]. However, according to the models, the variable characterising the cross-flow transport is different. The aim of this work was to show that the wall shear stress $\left(\tau_{\mathrm{w}}\right)$ is an appropriate parameter for the assessment of $\mathrm{J}_{\mathrm{lim}}$ and the critical flux ( $\left.\mathrm{J}_{\text {crit }}\right)$ compared to the Reynolds number ( $\mathrm{Re}$ ) and the mean crossflow velocity (v), and that they can be used for filtration scale-up. The experiments were applied to skimmed milk MF using a tubular ceramic membrane $(0.1 \mu \mathrm{m}$ mean pore diameter) for the separation of casein micelles from the soluble proteins.

\section{EXPERIMENTAL}

\subsection{Fluids}

Skimmed milk, heat treated at $63{ }^{\circ} \mathrm{C}$ for $15 \mathrm{~s}$, was provided by Compagnie laitière européenne (Montauban-de-Bretagne, France). It was heated to $50{ }^{\circ} \mathrm{C} 30 \mathrm{~min}$ before MF experiments, and $0.2 \mathrm{~g} \cdot \mathrm{L}^{-1}$ sodium azide was added to it to prevent any microorganism development.

List of symbols: $\mathrm{d}_{\mathrm{i}}$ : initial diameter of the tubular membrane $(\mathrm{m}) ; \mathrm{d}_{\mathrm{j}}$ : hydraulic diameter that remains open to flow $(\mathrm{m})$; Fa: Fanning factor $(-)$; Jt permeation flux $\left(\mathrm{m} \cdot \mathrm{s}^{-1}\right.$ or $\left.\mathrm{L} \cdot \mathrm{h}^{-1} \cdot \mathrm{m}^{-2}\right)$; $\mathrm{J}_{\text {crit }}$ : critical permeation flux $\left(\mathrm{m} \cdot \mathrm{s}^{-1}\right.$ or $\left.\mathrm{L} \cdot \mathrm{h}^{-1} \cdot \mathrm{m}^{-2}\right) ; \mathrm{J}_{\text {lim }}:$ limiting permeation flux $\left(\mathrm{m} \cdot \mathrm{s}^{-1}\right.$ or $\left.\mathrm{L} \cdot \mathrm{h}^{-1} \cdot \mathrm{m}^{-2}\right)$; L: length of the membrane tube $(\mathrm{m})$; $\mathrm{n}$ : channel number $(-)$; Qr: retentate flow rate $\left(\mathrm{m}^{3} \cdot \mathrm{s}^{-1}\right)$; Re: Reynolds number $(-)$; T: temperature $\left({ }^{\circ} \mathrm{C}\right)$; $\mathrm{v}$ : mean cross-flow velocity $\left(\mathrm{m} \cdot \mathrm{s}^{-1}\right)$; $\Delta \mathrm{d}$ : variation of the hydraulic diameter $(\%) ; \Delta \mathrm{P}$ : transmembrane pressure (Pa or bar); $\Delta \mathrm{P}_{1}$ : pressure drop along the membrane ( $\mathrm{Pa}$ or bar); $\gamma$ : wall shear rate $\left(\mathrm{s}^{-1}\right) ; \gamma_{\mathrm{L}}$ : wall shear rate defined in laminar regime according to equation $(5)\left(\mathrm{s}^{-1}\right) ; \gamma_{\mathrm{T}}$ : wall shear rate defined from equation $(4)\left(\mathrm{s}^{-1}\right) ; \mu_{\mathrm{r}}$ : dynamic viscosity of the retentate $\left(\mathrm{Pa} \cdot \mathrm{s}^{-1}\right) ; \rho_{\mathrm{r}}$ : density of the retentate $\left(\mathrm{m}^{3} \cdot \mathrm{kg}^{-1}\right) ; \tau_{\mathrm{w}}$ : shear stress at the membrane wall $(\mathrm{Pa})$. 
Water used in the MF rigs came from the laboratory tap water network and was filtered on $5 \mu \mathrm{m}$, then on serial cartridges of 1.0 and $0.2 \mu \mathrm{m}$.

The cleaning solutions were: Alkaline: P3-Ultrasil 13 (Henkel-Ecolab SNC; Issy-lesMoulineaux, France), $0.15 \%$ v/v; temperature $(\mathrm{T})=50^{\circ} \mathrm{C} ; \mathrm{v}=6 \mathrm{~m} \cdot \mathrm{s}^{-1} ; 15 \mathrm{~min}$ without permeation, 15 min with permeation flux $(\mathrm{J})=$ $240 \mathrm{~L} \cdot \mathrm{h}^{-1} \cdot \mathrm{m}^{-2}$. Acid: $\mathrm{HNO}_{3}$ (purity $58 \%$; Langlois Chimie, Saint-Jacques-de-la-Lande, France) $0.1 \% \mathrm{v} / \mathrm{v} ; \mathrm{T}=50^{\circ} \mathrm{C} ; \mathrm{v}=6 \mathrm{~m} \cdot \mathrm{s}^{-1} ; 15 \mathrm{~min}$ without permeation, $15 \mathrm{~min}$ with $\mathrm{J}=240 \mathrm{~L} \cdot \mathrm{h}^{-1} \cdot \mathrm{m}^{-2}$.

\subsection{Microfiltration rig, membranes and operating procedure}

Three filtration pilot rigs were used. All of them could operate either at controlled transmembrane pressure $(\Delta \mathrm{P})$ or at controlled J. All the experiments were performed using the cocurrent mode. This mode of operation consists of the circulation of the permeate co-current to the retentate in order to create a permeate pressure drop equal to the retentate pressure drop, so as to get no $\Delta \mathrm{P}$ difference along the hydraulic path [16].

Rig 1 consisted of the slightly modified rig described previously [6]: the retentate valve used to maintain the mean retentate pressure as constant during an experiment was replaced by a centrifuge feed pump and a relief valve. The used multichannel tubular Kerasep membranes (ORELIS, 01 Miribel, France) have the same membrane characteristics (alumina membrane on an alumina support, mean pore diameter $0.1 \mu \mathrm{m}$ ) but different geometries (see table I). The initial diameter of the cleaned membranes was determined in laminar regime using saccharose solutions of different viscosities. The

Table I. Operating parameters for the experiments performed with different membrane geometries. Tableau I. Conditions opératoires des expérimentations réalisées avec différentes géométries de membranes.

\begin{tabular}{|c|c|c|c|}
\hline \multirow[t]{2}{*}{ Controlled variable } & \multicolumn{3}{|c|}{ Geometry } \\
\hline & $\begin{array}{l}7 \text { channels } \\
\mathrm{d}_{\mathrm{i}}=4.3510^{-3} \mathrm{~m} \\
\mathrm{~L}=0.856 \mathrm{~m}\end{array}$ & $\begin{array}{l}7 \text { channels } \\
d_{i}=4.3310^{-3} \mathrm{~m} \\
\mathrm{~L}=0.40 \mathrm{~m}\end{array}$ & $\begin{array}{l}19 \text { channels } \\
d_{i}=2.7510^{-3} \mathrm{~m} \\
\mathrm{~L}=0.856 \mathrm{~m}\end{array}$ \\
\hline $\begin{array}{l}\text { Wall shear stress, } \tau_{\mathrm{w}} \\
\tau_{\mathrm{w}}=100 \pm 8 \mathrm{~Pa} \\
\left(\gamma_{\mathrm{T}}=168000 \pm 14000 \mathrm{~s}^{-1}\right)\end{array}$ & $\begin{array}{l}\gamma_{\mathrm{L}}=10100 \pm 200 \mathrm{~s}^{-1} \\
\operatorname{Re}=41500 \pm 800 \\
\mathrm{v}=5.50 \pm 0.05 \mathrm{~m} \cdot \mathrm{s}^{-1} \\
J_{\text {lim }}=76 \pm 2 \mathrm{~L} \cdot \mathrm{h}^{-1} \cdot \mathrm{m}^{-2}\end{array}$ & $\begin{array}{l}\gamma_{\mathrm{L}}=9900 \pm 200 \mathrm{~s}^{-1} \\
\operatorname{Re}=40100 \pm 800 \\
\mathrm{v}=5.35 \pm 0.05 \mathrm{~m} \cdot \mathrm{s}^{-1} \\
J_{\text {lim }}=75 \pm 2 \mathrm{~L} \cdot \mathrm{h}^{-l} \cdot \mathrm{m}^{-2}\end{array}$ & $\begin{array}{l}\gamma_{\mathrm{L}}=14800 \pm 300 \mathrm{~s}^{-1} \\
\operatorname{Re}=24200 \pm 500 \mathrm{~m} \cdot \mathrm{s}^{-1} \\
\mathrm{v}=5.09 \pm 0.05 \mathrm{~m} \cdot \mathrm{s}^{-1} \\
J_{\text {lim }}=74 \pm 2 \mathrm{~L} \cdot \mathrm{h}^{-1} \cdot \mathrm{m}^{-2}\end{array}$ \\
\hline $\begin{array}{l}\text { Wall shear rate, } \gamma \\
\gamma_{L}=10150 \pm 250 \mathrm{~s}^{-1}\end{array}$ & $\begin{array}{l}\tau_{\mathrm{w}}=100 \pm 8 \mathrm{~Pa} \\
\gamma_{\mathrm{T}}=168000 \pm 14000 \mathrm{~s}^{-1} \\
\mathrm{Re}=41500 \pm 800 \\
\mathrm{v}=5.50 \pm 0.05 \mathrm{~m} \cdot \mathrm{s}^{-1} \\
J_{\text {lim }}=76 \pm 2 \mathrm{~L} \cdot \mathrm{h}^{-1} \cdot \mathrm{m}^{-2}\end{array}$ & & $\begin{array}{l}\tau_{\mathrm{w}}=55 \pm 4 \mathrm{~Pa} \\
\gamma_{\mathrm{T}}=926000 \pm 7000 \mathrm{~s}^{-1} \\
\mathrm{Re}=16700 \pm 300 \\
\mathrm{v}=3.50 \pm 0.05 \mathrm{~m} \cdot \mathrm{s}^{-1} \\
J_{\text {lim }}=40 \pm 1 \mathrm{~L} \cdot \mathrm{h}^{-1} \cdot \mathrm{m}^{-2}\end{array}$ \\
\hline $\begin{array}{l}\text { Reynolds number, Re } \\
\operatorname{Re}=42200 \pm 1200\end{array}$ & $\begin{array}{l}\tau_{\mathrm{w}}=100 \pm 8 \mathrm{~Pa} \\
\gamma_{\mathrm{T}}=168000 \pm 14000 \mathrm{~s}^{-1} \\
\gamma_{\mathrm{L}}=10100 \pm 200 \mathrm{~s}^{-1} \\
\mathrm{v}=5.50 \pm 0.05 \mathrm{~m} \cdot \mathrm{s}^{-1} \\
J_{\text {lim }}=76 \pm 2 \mathrm{~L} \cdot \mathrm{h}^{-1} \cdot \mathrm{m}^{-2}\end{array}$ & & $\begin{array}{l}\tau_{\mathrm{w}}=275 \pm 20 \mathrm{~Pa} \\
\gamma_{\mathrm{T}}=464000 \pm 34000 \mathrm{~s}^{-1} \\
\gamma_{\mathrm{L}}=26300 \pm 600 \mathrm{~s}^{-1} \\
\mathrm{v}=9.05 \pm 0.05 \mathrm{~m} \cdot \mathrm{s}^{-1} \\
J_{\text {lim }}=\text { unstable }\end{array}$ \\
\hline $\begin{array}{l}\text { Cross-flow velocity, } v \\
v=5.50 \pm 0.05 \mathrm{~m} \cdot \mathrm{s}^{-1}\end{array}$ & $\begin{array}{l}\tau_{\mathrm{w}}=100 \pm 8 \mathrm{~Pa} \\
\gamma_{\mathrm{T}}=168000 \pm 14000 \mathrm{~s}^{-1} \\
\gamma_{\mathrm{L}}=10100 \pm 200 \mathrm{~s}^{-1} \\
\operatorname{Re}=41500 \pm 800 \\
J_{\text {lim }}=76 \pm 2 \mathrm{~L} \cdot \mathrm{h}^{-1} \cdot \mathrm{m}^{-2}\end{array}$ & & $\begin{array}{l}\tau_{\mathrm{w}}=117 \pm 8 \mathrm{~Pa} \\
\gamma_{\mathrm{T}}=197000 \pm 14000 \mathrm{~s}^{-1} \\
\gamma_{\mathrm{L}}=16000 \pm 200 \mathrm{~s}^{-1} \\
\mathrm{Re}=26180 \pm 500 \\
J_{\text {lim }}=83 \pm 2 \mathrm{~L} \cdot \mathrm{h}^{-1} \cdot \mathrm{m}^{-2}\end{array}$ \\
\hline
\end{tabular}


operating conditions of the experiments are given in table 1 . The experiments consisted of variations of $\Delta \mathrm{P}\left(0.0-1.0 \times 10^{5} \mathrm{~Pa}\right)$ at constant $\mathrm{v}$ (for experiments performed at constant Re, $\mathrm{v}$ or $\gamma_{\mathrm{L}}$, wall shear rate defined in the laminar regime according to equation (5); (see further in the Calculations section) or longitudinal pressure drop $\left(\Delta \mathrm{P}_{\mathrm{L}}\right)$ (for experiments performed at constant $\tau_{\mathrm{w}}$ or $\gamma_{T}$ wall shear rate defined from equation (4); (see further in the Calculations section) with 10 min duration at each step. Before each experiment, the skimmed milk was concentrated up to a volume reduction ratio (VRR) of $2\left(\Delta \mathrm{P}=0.1 \times 10^{5} \mathrm{~Pa}\right.$, duration about $\left.45 \mathrm{~min}\right)$. This level of the VRR was maintained as constant during all of the experiments by running MF in a feed and bleed mode of operation. These experiments made it possible to assess $\mathrm{J}_{\mathrm{lim}}$. All the experiments were performed in duplicate.

Rig 2 [10] was an MFS1 type (MicroFiltration System, Alfa-Laval, Lund, Sweden) equipped with a multichannel membrane consisting of an $\alpha$-alumina filtering layer on an alumina support (Membralox ${ }^{\oplus}$ membrane; SCT, Bazet, France: 19 channels, inner diameter $4 \mathrm{~mm}$, length $0.85 \mathrm{~m}$, membrane area $0.2 \mathrm{~m}^{2}$, mean pore diameter $0.1 \mu \mathrm{m}$ ). This pilot rig was composed of three pumps: a centrifuge feed pump maintaining the retentate pressure and two volumetric pumps for the circulation of fluids in the retentate and permeate compartments.

Rig 3 [6] was equipped with a monotube Membralox ${ }^{\circledR}$ membrane (SCT, Bazet, France) consisting of an $\alpha$-alumina filtering layer on an alumina support (inner diameter $6.8 \mathrm{~mm}$, length $0.75 \mathrm{~m}$, membrane area $1.60 \times 10^{-2} \mathrm{~m}^{2}$, mean pore diameter $0.1 \mu \mathrm{m}$ ).

The experiments with rigs 2 and 3 were performed over the course of time at various constant permeation fluxes and two cross-flow velocities. These experiments made it possible to define $\mathrm{J}_{\text {crit }}$ according to the methodology proposed by Le Berre and Daufin [11]. $J_{\text {crit }}$ is defined as the permeation flux below which there is no deposition on the membrane surface. Under $J_{\text {crit }}$ filtration performance is satisfactory (long MF time with slow increase of fouling and high solute transmission), and above $\mathrm{J}_{\text {crit }}$ performance is altered.

\subsection{Calculations}

The mean $\mathrm{v}$ was calculated from the retentate flow rate (Qr) as follows:

$$
\mathrm{v}=\frac{4 \mathrm{Qr}}{\mathrm{n} \pi \mathrm{d}_{1}^{2}}
$$

with $\mathrm{n}$, the channel number and $\mathrm{d}_{\mathrm{p}}$, the hydraulic diameter that remained open to flow during the experiment. $d_{1}$ corresponds to the initial membrane diameter reduced by the deposit thickness (see the Calculations section).

$\tau_{w}$ which represents the forces applied by the fluid flowing tangentially to the membrane on an element of membrane area, was experimentally determined according to:

$$
\tau_{\mathrm{w}}=\frac{\mathrm{d}_{1} \Delta \mathrm{P}_{\mathrm{L}}}{4 \mathrm{~L}}
$$

where $\Delta \mathrm{P}_{\mathrm{L}}$, is the longitudinal pressure drop and $\mathrm{L}$ is the length of the membrane tube. The pressure drop that should be used in equation (2) is that due to the flow through the filter tube. Bernouilli's equation has then been used to calculate the longitudinal pressure drop along the membrane tube once the pressure losses due to recirculation of flow before and after the filter have been removed from the measured value of pressure drop. Bernouilli's equation gave comparable results $(5 \%)$ to pressure corrections based on a hydrodynamic study of the module [7].

Re wa calculated as follows:

$$
\mathrm{Re}=\frac{\rho_{\mathrm{r}} \mathrm{vd}_{\mathrm{l}}}{\mu_{\mathrm{r}}}
$$

where $\rho_{\mathrm{r}}$ and $\mu_{\mathrm{r}}$ are the retentate density and dynamic viscosity, respectively. Whatever the experiment, the regime was turbulent $(\operatorname{Re} \gg>4000$; see table I).

The wall shear rate $(\gamma)$ was calculated in two different ways:

- directly from $\tau_{w}$ and $\mu_{r}$ measurements assuming the fluid to be newtonian at the membrane surface, $\gamma_{\mathrm{T}}$ :

$$
\gamma_{T}=\frac{\tau_{\mathrm{w}}}{\mu_{\mathrm{r}}}
$$

- by assuming a laminar velocity profile: the turbulence is severely damped at the membrane surface and the flow behaves as a laminar flow in some respects, $\gamma_{L}$ :

$$
\gamma_{L}=\frac{32 \mathrm{Qr}}{\mathrm{n} \pi \mathrm{d}_{1}^{3}}
$$

Piron et al. [13] apply equation (5) for the approximation of $\gamma$ in turbulent regime, assuming the retentate viscosity constant and the turbu- 
lence damped in the neighbourhood of the membrane.

The diameter that remains open to flow, $d_{1}$, decreased during the experiment due to the deposition of microorganisms, casein micelles, etc., at the membrane surface. The relation between $\tau_{\text {w }}$ and the Fanning factor (Fa) (equation 6) and the approximation of Blasius in turbulent flow, assuming the membrane to be a smooth tubular element (equation 6 ), enable $d_{1}$ to be worked out.

$$
\begin{aligned}
& \tau_{\mathrm{w}}=\frac{\mathrm{Fa}}{2} \rho_{r} \mathrm{v}^{2} \\
& \mathrm{Fa}=0.08 \mathrm{Re}^{-0.25}
\end{aligned}
$$

The rugosity of the clean Kerasep membrane, calculated with the Churchill correlation [14], was found to be $3 \times 10^{-6} \mathrm{~m}$. Since the rugosity is likely to decrease as a result of the deposition of casein micelles during the experiment, the diameter is given with a $5 \%$ accuracy and the pressure drop with an $8 \%$ accuracy.

The maximum variation of hydraulic diameter, $\Delta \mathrm{d}(\%)=\frac{\mathrm{d}_{1}-\mathrm{d}_{\mathrm{i}}}{\mathrm{d}_{\mathrm{i}}} \times 100\left(\mathrm{~d}_{\mathrm{i}}\right.$ initial hydraulic diameter of the clean membrane) over the course of the experiment was taken into account in the error specified for each variable $\left(v, R e, \tau_{w}, \gamma_{L}\right.$ and $\gamma_{\mathrm{T}}$ ) in table $l$.

\section{RESULTS AND DISCUSSION}

Figure 1 shows the evolution of the permeation flux versus $\Delta \mathrm{P}$ for experiments performed at similar $v, \operatorname{Re}, \gamma_{L}, \gamma_{T}$ and $\tau_{w}$ with different membrane geometries. Apart from experiments performed at very high cross flow $\left(\tau_{\mathrm{w}}=275 \mathrm{~Pa}, \operatorname{Re}=42200, \gamma_{\mathrm{L}}=26\right.$ $300 \mathrm{~s}^{-1}, \mathrm{v}=9.05 \mathrm{~m} \cdot \mathrm{s}^{-1}$; table $\mathrm{I}$ ), a limiting flux can be observed. This limiting flux is due to the deposit of casein micelles, microorganisms in the neighbourhood of the membrane $[9,11]$ and further investigations are in progress to understand the apparent instability of the deposit at high cross-flow transport.

As shown in figure $1, \tau_{w}$ and $\gamma_{\mathrm{T}}$ proved to be the most appropriate parameters to account for milk MF performance, since whatever the membrane geometry, the lim- iting flux was similar contrarily to what happened with $\mathrm{v}, \operatorname{Re}$ and $\gamma$. Moreover, when $\tau_{\mathrm{w}}$ (or $\gamma_{\mathrm{T}}$, directly calculted from $\tau_{\mathrm{w}}$ ) increased, the limiting flux increased (table I). These results contrasted strongly with those observed by Samuelsson et al. [15], who show that the limiting flux is a linear function of Re: in this work, two experiments performed with different membrane geometries and similar Re gave significantly different limiting fluxes.

The large discrepancy in the results observed with $\gamma_{\mathrm{T}}$ and $\gamma_{\mathrm{L}}$ (table I, figure I) emphasised the difficulty of evaluating the wall shear rate in turbulent regime. The calculation of the wall shear rate by assuming a Poiseuille flow (equation 5), as suggested by Piron et al. [13], was inaccurate: the mean crossflow velocity of the viscous sub-layer (difficult to determine) should have been taken into account in the calculation instead of $v$. The calculation of $\gamma$ from $\tau_{w}$ and the retentate dynamic viscosity (equation 4) also has limitations when the layers deposited on the membrane have a non-newtonian behaviour, which is the case in skimmed milk MF. $\gamma$, difficult to calculate in turbulent regime, could therefore not be considered in this work as an reliable parameter. Further investigations should be carried out in laminar regime to know whether is an effective parameter for the assessment of $\mathrm{J}_{\mathrm{lim}}$. Such experiments are, however, beyond the scope of this work since milk MF operations are mainly carried out in turbulent regime.

Although some authors believe that the decisive variable in the cake cross-flow filtration is $v$ [2], experimental evidence is accumulating in the literature and supports our results. Lu et al. [12] show, for example, that a decrease of the hydraulic diameter of the membrane under a given cross-flow velocity, which leads to an increase of membrane shear stress, improves performance. Aubert et al. [1] use $\tau_{w}$ to characterise the deposit thickness of carbon particles at the surface of a rotating membrane. Benkahla et al. [4] suggest that the cake growth limit 

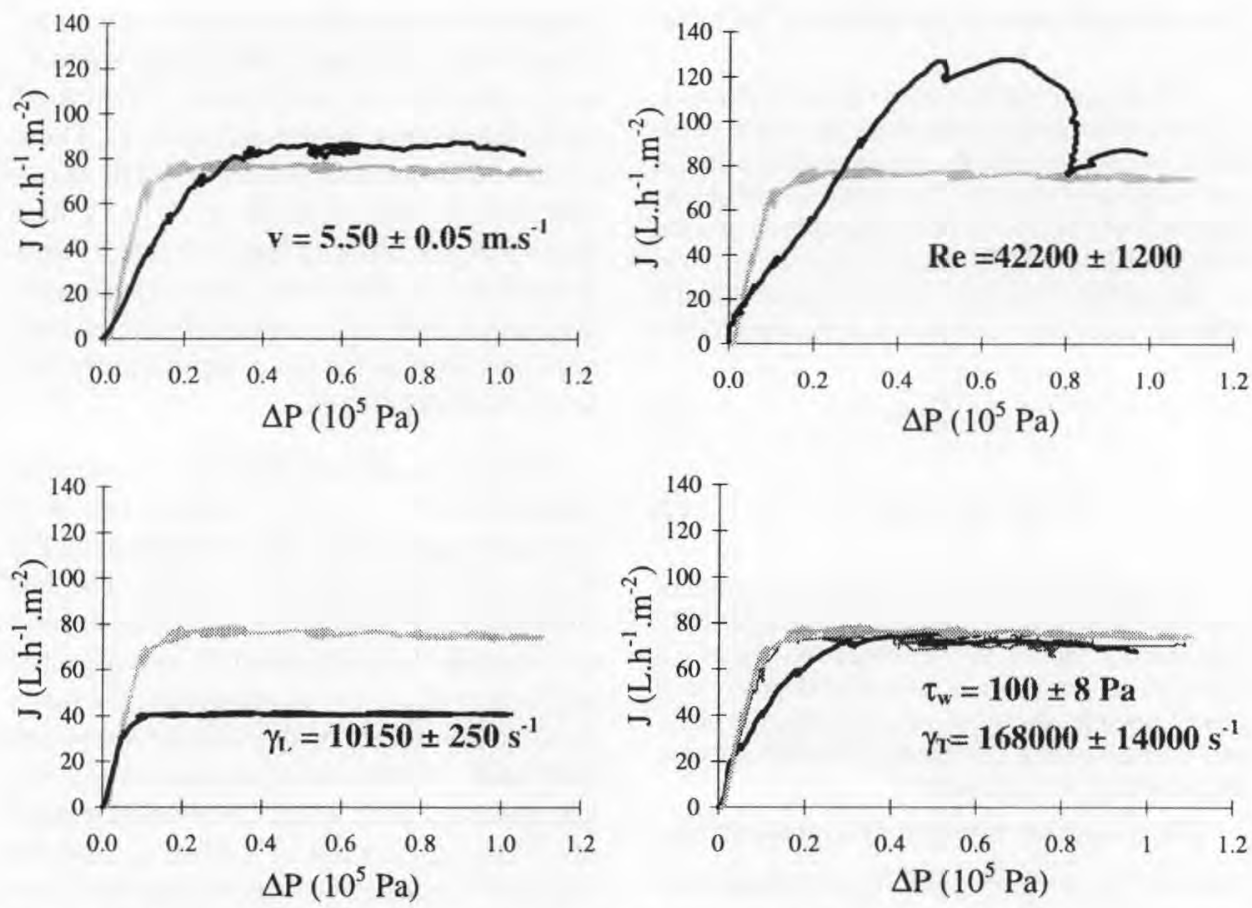

Figure 1. Permeation flux $(J)$ versus transmembrane pressure $(\Delta P)$ for experiments performed with different membrane geometries at constant cross-flow velocity (v), Reynolds number (Re), wall shear rates $\left(\gamma_{\mathrm{T}}\right)$ (eq. 4$)$ and $\gamma_{\mathrm{L}}$ (eq. 5) and wall shear stress $\left(\tau_{\mathrm{w}}\right) .(-): 7$ channels, $0.4 \mathrm{~m} ;(-)$ ): 19 channels, $0.856 \mathrm{~m}$; ( $): 7$ channels, $0.856 \mathrm{~m}$.

Figure 1. Densités de flux de perméation, $\mathrm{J}$ en fonction de la pression transmembranaire, $\Delta \mathrm{P}$ pour des expérimentations réalisées avec différentes géométries de membranes à même vitesse moyenne d'écoulement tangentiel, v, même nombre de Reynolds, Re, même taux de cisaillement à la membrane $\gamma_{\mathrm{T}}$ (Eq. 4) et $\gamma_{\mathrm{L}}$ (Eq. 5) et même contrainte de cisaillement, $\tau_{\mathrm{w}^{*}}$ ( -7 canaux ; 0,4 $\mathrm{m}(-) 19$ canaux ; $0,856 \mathrm{~m} ;(-) 7$ canaux $; 0,856 \mathrm{~m}$.

can be attributed to the Coulomb failure criterion defined by a relation taking into account shear and normal stresses acting on the cake as well as the friction coefficient and the cohesion of the deposit. According to $\mathrm{Wu}$ et al. [17], $\tau_{\mathrm{w}}$ should be employed to characterise the cross-flow transport because it considers the changes in modules characteristics and cross-flow velocity but also the changes in viscosity in the course of an experiment.

The representation of $\mathrm{J}_{\text {crit }}$ (under which fouling is low) vs. $\tau_{w}$ (or $\gamma_{\mathrm{T}}$ ranging from
125000 to $250000 \mathrm{~s}^{-1}$ ) demonstrated a good correlation between experimental data obtained with two different rigs and membrane geometries (figure 2), contrary to like $\mathrm{v}, \operatorname{Re}$ and $\gamma_{\mathrm{L}} \cdot \tau_{\mathrm{w}}$ consequently seemed to be an appropriate parameter to study filtration scale-up since it made it possible to determine the critical operating conditions of a system $\left(\mathrm{J}_{\text {crit }}, \mathrm{J}_{\text {lim }}\right)$, whatever the geometry of the membrane and the membrane surface. Recent publications pointing out the existence of a $J_{\text {crit }} / \tau_{w}$ ratio $[5,8,11]$ reinforced this result. 

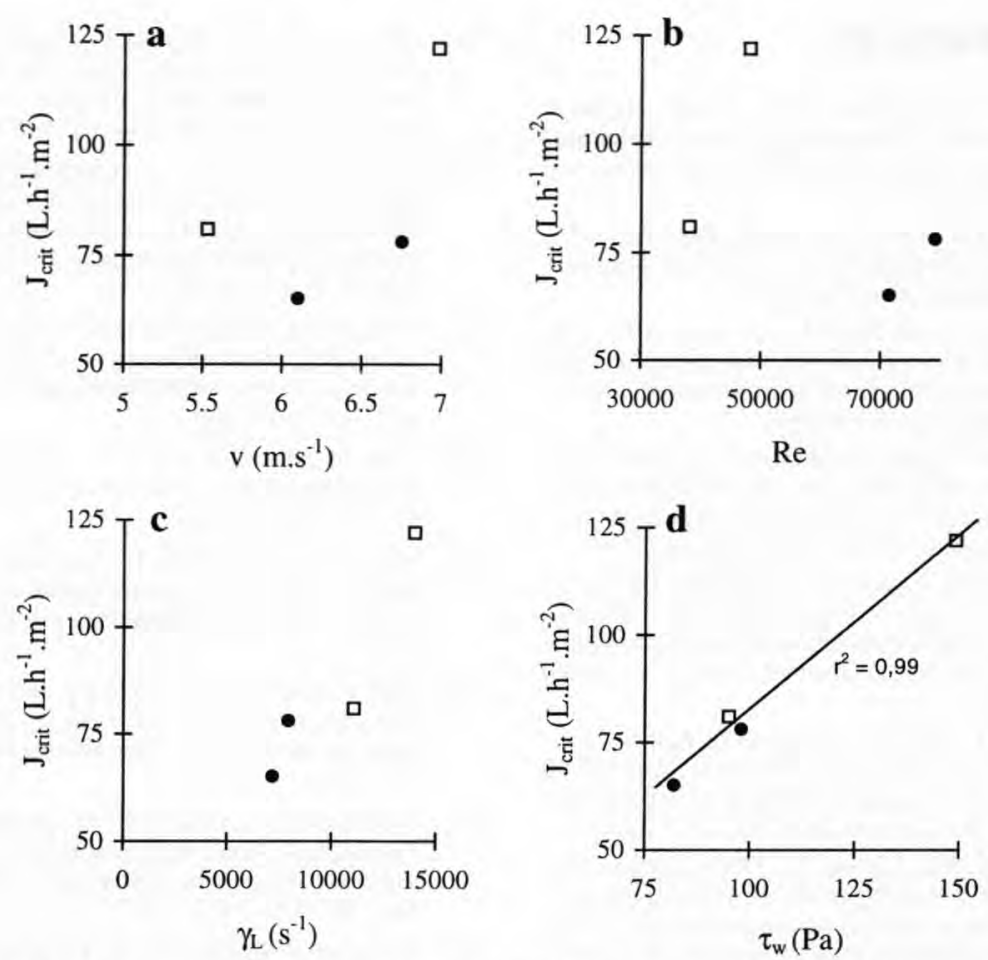

Figure 2. Critical permeation fluxes $\left(\mathrm{J}_{\text {crii }}\right)$ obtained with two different membrane geometries: $(\square)$ multichannel, 19 channels $\left(0.2 \mathrm{~m}^{2}\right.$; initial diameter of the membrane tube $\left[\mathrm{d}_{\mathrm{i}}\right]=4 \times 10^{-3} \mathrm{~m}$; length of the tube $[\mathrm{L}]=0.85 \mathrm{~m}) ;(-)$ monotube $\left(0.02 \mathrm{~m}^{2} ; \mathrm{d}=6.8 \times 10^{-3} \mathrm{~m} ; \mathrm{L}=0.75 \mathrm{~m}\right)$ versus a) mean cross-flow velocity (v); b) Reynolds number (Re); c) wall shear rate $\left(\gamma_{L}\right.$, eq. 5); and d) wall shear stress $\left(\tau_{w}\right)$.

Figure 2. Densités de flux de perméations critiques obtenues avec deux géométries de membranes : (口) multicanal, 19 canaux $\left(0,2 \mathrm{~m}^{2} ; \mathrm{d}_{\mathrm{i}}=4 \times 10^{-3} \mathrm{~m} ; \mathrm{L}=0,85 \mathrm{~m}\right) ;(-)$ monotube $\left(0,02 \mathrm{~m}^{2}\right.$; $\left.\mathrm{d}_{\mathrm{i}}=6,8 \times 10^{-3} \mathrm{~m} ; \mathrm{L}=0,75 \mathrm{~m}\right)$ en fonction de : a) vitesse moyenne d'écoulement tangentiel, $\mathrm{v}$; b) nombre de Reynolds, Re ; c) taux de cisaillement à la membrane, $\gamma_{\mathrm{L}}(\mathrm{Eq} .5)$; d) contrainte de cisaillement à la membrane, $\tau_{\mathrm{w}}$.

\section{CONCLUSION}

Unlike Re and v, which are parameters classically used to characterise cross-flow transport, $\tau_{\mathrm{w}}$ made it possible to assess the $\mathrm{J}_{\lim }$ and $\mathrm{J}_{\text {crit }}$ in milk MF $(0.1 \mu \mathrm{m})$, whatever the membrane geometry (length, channel number, hydraulic diameter). $\tau_{w}$ was consequently an effective parameter to characterise the cross-flow transport, to account for cake filtration and to study the crossflow filtration scale-up.

The wall shear rate $\gamma$, calculated by assuming the turbulence damped at the membrane surface and the flow behaviour laminar, was not a satisfactory parameter for controlling the process in turbulent regime. It proved $\gamma$ to be difficult to calculate in turbulent regime, and further investigations should be performed in order to clarify its effectiveness in controlling the process.

\section{ACKNOWLEDGEMENTS}

We thank M. Garnier for technical assistance with the rig built-up and D. Jacob for setting up the regulations of microfiltration operating conditions. 


\section{REFERENCES}

[1] Aubert M.C., Elluard M.P., Barnier H, Shear stress induced erosion of filtration cake studied by a flat rotating disk method, J. Membrane Sci. 84 (1993) 229-240.

[2] Baker R.J., Fane A.G., Fell C.J.D., Yoo B.H., Factors affecting flux in crossflow filtration, Desalination 53 (1985) 81-93.

[3] Belfort G., Davis R.H., Zydney A.L., The behaviour of suspensions and macromolecular solutions in crossflow microfiltration, J. Membrane Sci. 96 (1994) 1-58.

[4] Benkahla Y.K., Ould-Dris A., Jaffrin M.Y., Si-Hassen D., Cake growth mechanism in crossflow microfiltration of mineral suspensions, J. Membrane Sci. 98 (1995) 107-117.

[5] Boyaval P., Lavenant C., Gésan G., Daufin G., Transient and stationary operating conditions on performance of lactic acid bacteria crossflow microfiltration, Biotechnol. Bioeng., 49 (1996) $78-86$.

[6] Daufin G., Radenac J.F., Gésan G., Kerhervé F.L., Le Berre O., Michel F., Merin U., A novel rig design for ultra and microfiltration experiments, Separ. Sci. Technol. 28 (1993) 2635-2642.

[7] Fillaudeau L., Lalande M., Déterminations analytique et numérique des pressions transmembranaires en microfiltration tangentielle - Validation expérimentale, Entropie 209 (1998) $25-34$.

[8] Gésan G., Daufin G., Merin U., Performance of whey microfiltration during transient and stationary operating conditions, J. Membrane Sci., 104 (1995) 271-281.
[9] Gésan-Guiziou G., Boyaval E., Daufin G., Critical stability conditions in crossflow microfiltration of skimmed milk: transition to irreversible deposition, J. Membrane Sci. (1999) in press.

[10] Le Berre O., Microfiltration tangentielle de lait appliquée à la séparation des micelles de caséine des protéines solubles : aspects hydrodynamiques et physico-chimiques, thèse ENSA, Rennes, France, 1996.

[11] Le Berre O., Daufin G., Skim milk crossflow microfiltration performance versus permeation flux to wall shear stress ratio, J. Membrane Sci. 117 (1996) 261-270.

[12] Lu W.M., Hwang K.J., Lu S.C., Studies on the mechanism of crossflow filtration, Chem. Eng. Sci. 48 (1993) 863-872.

[13] Piron E., René F., Latrille E., A crossflow microfiltration model based on integration of the mass transport equation, J. Membrane Sci. 108 (1995) 57-70.

[14] René F., Leuliet J.C., Delplace F., Friction factors and roughness measurements of tubular mineral membranes, Exp. Fluids 15 (1993) 175-182.

[15] Samuelsson G., Huisman I.H., Tragardh G., Paulsson M., Predicting limiting flux of skim milk in crossflow microfiltration, J. Membrane Sci., 129 (1997) 277-281.

[16] Sandblöm R.M., (Alfa-Laval) Filtering Process, Swedish Patent, 7416 257, 1974.

[17] Wu D., Field R., Howell J., Filtration behaviour of baker's yeast suspensions at very high concentrations, Separ. Sci. Technol. 30 (1995) 1473-1490. 